Irish Theological Quarterly 72 (2007) 96-104

(C) 2007 Irish Theological Quarterly Sage Publications, Los Angeles, London,

New Delhi and Singapore

DOI: $10.1177 / 0021140007079393$

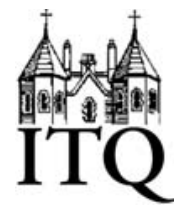

COMMENTARY

\title{
On Tanner's 'Economy of Grace': An Economist Responds
}

\author{
Rowena Pecchenino \\ Department of Economics, Michigan State University
}

Kathryn Tanner constructs a theological economic system based on the tenets of grace. Her system, which attempts to address Christianity's concern for fundamental economic rights, is ultimately flawed. I establish how her theological economic system is built on faulty assumptions, while determining whether the key benefits that she identifies as outcomes can be achieved in the current competitive market system.

KEYWORDS: Economics, Grace, Property Rights, Public Goods, Social Welfare

Ka athryn Tanner introduces her Economy of Grace as a conversation between the disciplines of theology and economics. ${ }^{1}$ Her goal is to replace the motive forces which propel the economic system, which she identifies as property and possession, ${ }^{2}$ with the Christian imperatives of love of God and love of neighbour, ${ }^{3}$ while still maintaining the superstructure of the capitalist system. ${ }^{4}$ She contends that not only can this be done, but it must be done since the current system is in danger of continuing to spiral ever downwards into misery and despair. ${ }^{5}$ And, further, if it is done, the downward cycle of despair will be replaced by an upward cycle of mutual benefit and gain. ${ }^{6}$ While a conversation is proposed, a monologue rather than a dialogue is actually conducted since, in her discussion, the discipline of economics is not well represented nor are its practitioners consulted. ${ }^{7}$ This article attempts to remedy this.

1. Kathryn Tanner, Economy of Grace (Minneapolis, MN: Fortress Press, 2005).

2. Ibid., 34. However, economists would see the motive forces driving the economy as the pursuit of profits by firms, of social welfare by governments, and of utility (well-being) by individuals, families, or other well-defined social groups. Property and possession are, at best, a means to these ends.

3. Ibid., 85 .

4. Economists would use the term competitive market system rather than capitalist system as it is more accurate and precise. It is also less tainted with ideology since capitalism is often seen as the 'bad' to the 'good' of Marxism.

5. Tanner, Economy of Grace, 32, 115, 121.

6. Ibid., 114.

7. Tanner is a Professor of Theology at the University of Chicago. While she acknowledges many in the Theological community for their assistance and comments on her text, she did 
Designating herself as a 'constructive theologian, ${ }^{8}$ Tanner's method is to construct an economy based on theological principles which she proposes as a superior alternative to the current economic system. She argues in the first chapter, 'An Economy of Grace?,' that she is working in the long Christian tradition of concern for economic outcomes; the allocation of the goods of the earth, a tradition which would seem to find its basis in living out Jesus' commandments that 'you shall love the Lord your God with all your heart, and with all your soul, and with all your mind, and with all your strength $\ldots$ and you shall love your neighbour as yourself' (Mark 12:30-31). ${ }^{9}$ But, instead of operating on the periphery and only responding ex post to economic outcomes, as has become common for Christian churches in the West, ${ }^{10}$ Tanner places Christianity at the centre of economics, ${ }^{11}$ building the economic system from a Christian core and making the Christian ethos a fundamental force in economic decision-making, while taking as given the underlying structure of the market economy.

Tanner develops her theology in three steps. First, in Chapter 1, she establishes a correspondence between economics and theology. This is crucial to constructing a theology of the economy, or a theological economic system. Second, at the beginning of Chapter 2,12 she examines three economic systems, capitalist, Lockian, and gift-exchange, to determine whether they could form the basis of a theological system. While she finds each of the systems deficient, she gleans lessons from each. Finally at the end of Chapter 2,13 she constructs her own theological economic system based on the tenets of grace. These are unconditional giving, humankind's proper response to God's love and infinite concern, and noncompetitiveness, the economy as portrayed in early Christian writings. ${ }^{14}$ She closes, in Chapter 3, by asserting that this theological economic system can evolve from the current system. Further, she argues that by implementing public policies consistent with her theological system, even in the context of the current system, all will live happier, more fulfilled lives.

The economic system she develops, the means by which Christianity's concern with fundamental economic rights, 'the right to life and all the

not seek out her colleagues in the Department of Economics at the University of Chicago, which is considered to be one of the top-five departments of economics in the world, for comment or for guidance. Rather, her conversation is more with sociologists or cultural critics than with economists, as her key references concerning economics and economic systems are to Max Weber, Pierre Bourdieu, Jean-Joseph Goux, Claude Lévi-Strauss and others better known outside the discipline of economics than within it.

8. Tanner, Economy of Grace, $\mathrm{x}$.

9. Ibid., 1-29.

10. See David C. Hester, 'The Sanctified Life in the Body of Christ: A Presbyterian Form of Christian Community,' in Community Formation in the Early Church and in the Church Today, ed. Richard N. Longenecker (Peabody, MA: Hendrickson, 2002), 194-212.

11. Tanner, Economy of Grace, 1.

12. Ibid., 31-61.

13. Ibid., 62-85.

14. Although not referenced, her economic model draws its inspiration from Acts 2: 44-5. 
goods of life, ${ }^{15}$ is fulfilled, is, ultimately, flawed. To establish this, I examine the theological economic system she develops ${ }^{16}$ on its own merits by offering a critique of the economic reasoning upon which it is based. I reply first to her response to capitalism ${ }^{17}$ and to Locke. ${ }^{18} \mathrm{I}$ do this in three steps: first, by re-examining the competitive market economy to establish what it can and cannot do; second, by examining the important role played by the legal system for the efficient operation of the market economy, paying special attention to the definition and protection of property rights; and, third, by discussing the role of government in the reallocation of resources. Then I establish how her theological economic system is built on faulty assumptions, while determining whether the key benefits she identifies as outcomes of her system can be achieved in the current system.

Tanner's basic premise is that, however unworthy we are, the grace of God bestows upon us the right to a fulfilled life, both materially and spiritually. The economic system, therefore, should be a mechanism ensuring that God's intended distribution of material resources is actually achieved, bringing both material and spiritual fulfilment. ${ }^{19}$ But, since some among us do not have access to all the goods of life, ${ }^{20}$ the system clearly has failed to achieve its God-ordained goal. This (failed) system is the now prevalent competitive market (capitalist) system. ${ }^{21}$

The competitive market system, as it exists in practice, is an economic system overlaid with regulations to solve problems caused by market failures; a legal system to protect all types of property and to enforce contracts; and government-initiated social welfare policies to redistribute economic wealth in a more equitable manner. Free market (capitalist) economies are characterized by a healthy respect for the power of the market, both when markets work and when they fail. Consider first the ideal of perfect competition. In the ideal, competitive markets lead to goods being produced by the most efficient producers, that is, at least cost. Competition among producers means that none has any market power, that is, producers cannot set the price but must accept the price determined in the market. In markets where producers do have some market power and so make extraordinary profits, competitive forces are brought to bear as other producers enter to capture some of those industry profits. What is true for output markets, the market for goods and services, is also true for input markets, the markets for the basic means of production: capital and labour. The competitive forces which drive the market system lead to an efficient allocation of resources taking as given the initial allocation of resources.

15. Tanner, Economy of Grace, 73.

16. Ibid., 62-85.

17. Ibid., 32-40.

18. Ibid., 40-46.

19. Ibid., 77.

20. Ibid., 32.

21. Ibid., 33. 
Competition in the input markets ensures that workers and owners of capital are fully compensated for the inputs they supply to the production process: they are paid their marginal products. This does not mean that either workers or owners of capital will earn enough to ensure a fulfilled life. Rather it means that the market valuation of their inputs is correct given the relative supplies of those inputs and the market valuation of output which depends on market demand for that output. That is, if labour is plentiful and capital scarce, then the return to labour (the market wage) will be relatively low and the return to capital (the interest rate) will be relatively high, reflecting only the relative value of each to the production process and final demand for the good or service produced. The competitive market system ensures allocative efficiency not equity, where equity could be defined as the right to a fulfilled life. This is because, to the market, all economic actors are anonymous and special considerations are not given to compensate for inequalities of opportunity or extra-economic misfortunes or other differences in initial conditions. ${ }^{22}$

While the competitive market does not reallocate resources from those who have to those who have not, it does provide signals to economic actors so that they can choose how best to allocate the resources they have to achieve the highest material gain. Thus, if capital is scarce, the return to capital will be high. This leads individuals to invest in capital. Or, if there is a shortage of skilled labour, then the wages paid to skilled workers will be high. This leads individuals to invest in gaining those skills. For example, suppose that IT industry workers earn 50 Euro an hour and vacancy rates are high (jobs are going unfilled) while insurance industry workers earn half that. Then, workers in the insurance industry could increase their wages significantly by gaining the skills needed to obtain employment in the IT industry. The market signals where profit opportunities exist, and individuals, trying to avail themselves of those opportunities, compete the excess profits away. In the end, that is, in market equilibrium, both capital and labour are fully, but not over, compensated. Where those profit opportunities are does not concern the market. ${ }^{23}$ Further, the market does not compensate those hurt by the adjustment of the market, those that suffer from the pecuniary externalities wrought by changes in prices which signal increased profit opportunities in some sectors while diminished ones in other sectors (jobs in some sectors are lost

22. A single mother caring for a disabled child may be unable to hold down a job in the market because of nonmarket demands on her time. The market does not discriminate against her because she is a single mother caring for a disabled child. Rather, she is determined to be unable to meet the requirements of employment (unable to provide her labour services consistently), and is, thus, unemployable. See Tanner, Economy of Grace, 39.

23. Thus, if there are profit opportunities in life-style drugs, pharmaceutical firms, and the capital and labour they control, will invest in research and development into these drugs, not into drugs that may lead to longer, healthier lives of the impoverished AIDS sufferers in developing countries, but for which profit opportunities are absent. See Tanner, Economy of Grace, 39. 
while in other sectors they are gained, or capital in some sectors is made obsolete when demand shifts from one good to another). ${ }^{24}$ Again, simply and exclusively, the competitive market ensures allocative efficiency.

When markets fail, such as when outputs are public goods which benefit all collectively but to which access cannot be restricted so prices cannot be charged, or when actions of one agent impose an externality, an uncompensated effect, on another agent, whether good or bad, the government can produce and allocate the public good, or assign property rights over the external effect, and either tax the agent imposing the negative externality or subsidize the agent generating the positive externality. In both cases the government's actions 'create' a market where the market system itself fails to do so. But the market, on its own, makes neither ethical nor moral judgements, nor does it compensate those hurt by the efficient operation of the market. These are the roles of the government, on which more below.

Underlying the competitive market system is a legal system that protects property rights and enforces contracts. Given ownership - whether by an individual, a group of individuals, such as a family, a business firm, or a collective, such as the citizens of a country - property rights define the conditions of use and disposition. Tanner is concerned that property rights are generally exclusive, and so one's ownership of a resource excludes another's use, unless by mutual agreement. ${ }^{25}$ This is, indeed, the case. But, in most situations, well-defined and protected property rights protect all. For example, an individual has property rights over his person, and so over his labour. He can enter into an employment contract which specifies the conditions of employment, the wage, and any job-related benefits. This contract is legally enforceable, and so the employer, contra Tanner, ${ }^{26}$ cannot without risk of censure reduce the wage or increase the number of hours of work required as a means of increasing profits at the workers' expense: employers cannot legally exploit their workers when property rights are protected. True, the employer could fire all current workers and hire replacement

24. For example, firms may choose to move their production offshore: the market has signalled that foreign workers are cheaper than and as productive as their domestic workers. The firm fires its high-wage domestic workers and hires lower-wage workers abroad. The firm thus takes advantage of the lack of integration of the domestic and foreign labour markets. This staffing choice is profitable only in the short-run as markets adjust and the world labour market integrates into a single market. In the longer run wages in developing countries will rise while wages in developed countries will fall (or remain stagnant). In market equilibrium wages for equivalent workers anywhere in the world will be equalized. The cost of this adjustment on first world workers will be high while the benefit to third world workers will also be high. Economic efficiency is enhanced by this process and the net gain is positive. But there are losers. See Albino Barerra, Economic Compulsion and Christian Ethics: New Studies in Christian Ethics (Cambridge: CUP, 2005); Richard Freeman, 'Labor Market Imbalances: Shortages, or Surpluses, or Fish Stories?,' Mimeograph, Harvard University, 2006 (http://www.bos.frb.org/economic/conf/conf51/papers/freeman.pdf).

25. Tanner, Economy of Grace, 34-40.

26. Ibid., 38, 107. 
workers at a lower wage or for longer hours, but within an integrated labour market, such as the labour market in a single country or region, these lower-wage workers will not be as productive as the fired workers (a lower wage implies a lower marginal product). Profits will rise only if the employer increases the efficiency of the production process. Property rights are also defined over physical property, such as land and capital, financial capital, and intellectual property, such as technology.

When property rights are well defined and legally enforced, only the owner of property can determine the conditions of its use or sale: no one can use another's property without leave. This is because using property changes its value. For example, capital, such as a machine, depreciates with use. If a machine owned by $\mathrm{A}$ is used by $\mathrm{B}$ because property rights are poorly defined and not legally enforceable, A will not be compensated and suffer an unrecoverable loss. Or, land owned by A may be improved by B and the value of the property may be enhanced. Without well-defined or enforceable property rights, the question of who has rights to the enhancements and the profit stream they produce is ambiguous. And where property rights are not well defined or well protected, investments, such as foreign direct investment from the developed to the developing economies, will not be made, nor will financial capital flow since rights to the investment are not legally defined and the profits it generates are not legally protected. ${ }^{27}$ The problem Tanner attributes to property rights rights with a strong biblical precedent, as in Joshua and the covenantal laws in Deuteronomy - is not a problem with rights to property per se, but with the very unequal distribution and protection of those rights.

This returns us to the role of the government, an essential actor in the competitive market system, and the institution which can assess and address issues of economic equity by reallocating resources. Economic inequality has many sources, among them inequality of opportunity, inequality of talents and inequality of tastes. Thus, since poverty is a relative measure, the poor will always be with us even if we all start with exactly the same resources. Clearly, many of those considered poor in the United States or Europe today would have been considered well off in the United States or Europe of a century ago or in most parts of the developing world today. The challenge facing any government is to determine how poverty can be alleviated, or at least ameliorated, without impoverishing the economy as a whole.

27. One reason why international 'financial' capital does not flow into developing countries or into long-term productive investments is that the risk in terms of unprotected property rights (the fear of expropriation) are too high given expected returns. Countries with well-protected property rights and stable legal institutions are recipients of foreign direct investment and of international lending. Many of the poorest countries who could most benefit from such investment do not fall into this category. See Joshua Aizenman and Mark Spiegel, 'Institutional Efficiency, Monitoring Costs, and the Investment Share of FDI,' Review of International Economics 14 (2006): 683-97, in contrast to Tanner, Economy of Grace, 125. 
Poverty alleviation, or providing a minimum standard of living for all, which could be considered a guarantee of the right to a fulfilled life and all the goods of life, is the essence of most government-funded social welfare policies. To fund these programs taxes must be imposed and transfers made in such a way as to minimize negative effects on the economy. These negative effects, which are largely incentive effects, must be confronted. ${ }^{28}$ To understand why, suppose that taxes are imposed on labour income. If, after tax, wages are reduced sufficiently, some individuals will withdraw their labour from the market since they evaluate the value of their time as greater than the after-tax wage. As a result, less will be produced, and, all else equal, tax revenues will be lower than anticipated..$^{29}$ Or suppose taxes are imposed on the returns to capital. This reduces the incentive to save, that is, to invest in capital, reducing capital, and, often, reducing the rate of economic growth. Or suppose a minimum income is provided to all, whether working, looking for work, or out of the labour force. To many workers and job seekers this income guarantee would be preferable to working as it would generate a higher expected income and leave them the time to pursue other activities. They would exit the labour force to avail themselves of the benefit, especially if this benefit is viewed as a right due to all irrespective of opportunities. Social opprobrium, which often limits take up of unemployment insurance benefits and other social welfare payments, ${ }^{30}$ would not keep people from availing themselves of these benefits if they were truly viewed as rights. The cost to the system if the benefit levels were set such that all could enjoy all the goods of life could be crippling, leading to a reduction in what can realistically be defined as all the goods of life. Overcoming these incentive problems, which do exist in the current system and will also exist in Tanner's system, is essential.

Using our understanding of the free market economy, we can now analyze Tanner's economy of grace. The first pillar of Tanner's economic structure is unconditional giving, which she defines as the proper response to God's gift of grace. ${ }^{31}$ While God gives, regardless of whether we are worthy recipients of the gifts, and can continue to give without constraint, human beings, all Tanner's arguments to the contrary, do not have this luxury. There are constraints on what can be given and there are opportunity costs

28. See Gareth D. Myles, Public Economics (Cambridge: CUP, 1995) or any textbook on public economics for a discussion of tax distortions.

29. A case in point is the economy of the Republic of Ireland in the 1980s when there were few incentives to work because of high taxes both on income and employment. Further, because of the nature of the unemployment benefit, not working could 'pay' better than working. When it did, individuals responded to the incentives by not working, contrary to Tanner's prediction. See Tanner, Economy of Grace, 104. The universalistic principles underlying Irish social services at the time are what Tanner is advocating. See Tanner, Economy of Grace, 101. These, however, led not to economic growth but to economic decline.

30. For an analysis of this phenomenon, see Martin Dufwenberg and Michael Lundholm, 'Social Norms and Moral Hazard,' Economic Journal 111 (2001): 506-25.

31. Tanner, Economy of Grace, 66-72. 
associated with giving that affect humans but not God. For humankind, productive resources are scarce. Thus, for individuals to be willing to pay taxes or to make charitable donations to benefit others, the net loss they suffer from not using these resources must be balanced by the net benefit of others using them. Benefits must flow to those for whom they provide the greatest good. Thus, in allocating tax revenues governments impose conditions which try to ensure that those most in need, those least able to provide for themselves and who will benefit most, receive the government transfers and use them wisely. Social welfare benefits are not available to all and are conditional on, for example, receiving training to improve employment chances, seeking employment, being disabled and unable to work. And they may be limited by the lifetime benefits that one receives or one's personal means. The real question is what form these benefits should take, how resources should be reallocated. Should they be transfers of income or of assets or a combination of the two? The first method ameliorates existing poverty by allowing the poor to purchase goods and services, but, perhaps, does not address the causes of poverty, thereby masking rather than solving the problem. The second method creates more equality of opportunity, providing the recipients the means to avoid or to move out of poverty through their own effort since greater equality of opportunity gives greater access to, for example, education and the credit market, which lead to better earnings potential both on one's own labour and on the capital one owns. The third recognizes that even with more equal opportunities some will excel and others will fail. However resources are reallocated, because of limited resources, all social welfare benefits will be given conditionally, not unconditionally: the right to all the goods of life comes with obligations. ${ }^{32}$

The second pillar of Tanner's economic structure is noncompetitiveness ${ }^{33}$ whereby all resources are held in common and utilized jointly and simultaneously without loss. ${ }^{34}$ This creates an ownership structure similar to that of an ideal Christian congregation as portrayed in Acts in which all, which to Tanner means all members of the world community, together, work for the common good. But, for this to be possible all nonhuman resources must have the characteristics of pure public goods, goods which all can use and use simultaneously without diminution of value - they are nonrival and nonexcludable. Most goods, even public goods, do not have these characteristics. Rather, they are rival and excludable. Consider, for

32. Paul can be seen addressing the same issues for the Thessalonians in 2 Thess 3 . While acknowledging the right to support of community members by the greater community, he also reminds them that the right to support is a privilege not to be abused.

33. Tanner, Economy of Grace, 75-85.

34. Tanner, Economy of Grace, 76, states 'First, there is no competition in property or possession. Something can be my property at the same time as it is another's [common property]; my having something in my possession need not lessen the degree to which it is in another's [non-rival]. Second, there is no competition between having oneself and giving to others [nonexcludable].' Square brackets RP. 
example, public roads: the more people use the roads simultaneously, the greater the traffic and the longer the commute time, which diminishes their value (roads are rival); and to reduce congestion access charges can be imposed (roads are excludable). Land used for agriculture or grazing is also rival: if $\mathrm{A}$ grazes his cattle there may not be enough pasturage left for $\mathrm{B}$ and $\mathrm{C}$ to graze theirs, or if $\mathrm{A}$ grows crops on the land $\mathrm{B}$ and $\mathrm{C}$ cannot also grow crops on the same land. Further, land under common ownership may not be maintained, as it will be impossible for those who do the maintaining to capture the returns to the maintenance investment. Indeed, not only land but also physical capital is rival and excludable as is financial capital. Common ownership does not change this. It does not obviate the need for well-defined and legally enforced property rights because although what is mine may be yours, we still cannot use it simultaneously for our own ends and to fulfil our own needs, even if those ends and needs are communal in nature. Making property common, her call for noncompetitiveness, does not alleviate distributional or allocational problems. Specific property rights and rules for allocating those rights are still required. ${ }^{35}$

This brings us back to the basic problem: the allocation of resources and opportunities. For resources and opportunities to be reallocated so that they are, or will become, consistent with God's design, members of the world community have to agree that the current allocation is inequitable and that a more equitable distribution would benefit all, either materially, spiritually, or both. Then following Barrera, members of the world community must devise both national and international tax and transfer schemes 'to fill the lacunae of the marketplace since we are bound to each other by mutual obligations of assistance and care. ${ }^{36}$ Doing so would bring about a 'theological' economic system. To do so we need to recognize that we are indeed bound together. Perhaps, that we do not recognize this points to a failure of theology not of economics.

ROWENA PECCHENINO, Professor of Economics, Michigan State University, has published in the fields of macro, banking, growth, defense, environmental and health economics. Her work has appeared in, for example, the American Economic Review, Economic Journal and the Journal of Public Economics. Her current research explores the interface between economics and theology. Address: Department of Economics, Michigan State University, Canada. rowenap@msu.edu

35. See Hervé Moulin, Fair Division and Collective Welfare (Cambridge, MA: MIT, 2003) for a discussion of the difficulties involved in fairly allocating property rights and final goods when there is common ownership.

36. Barerra, Economic Compulsion, 226. 